Aliens and Sojourners 
Divinations: Rereading Late Ancient Religion

Series Editors: Daniel Boyarin, Virginia Burrus, Derek Krueger

A complete list of books in the series is available from the publisher. 


\section{Aliens and Sojourners}

Self as Other in Early Christianity

BENJAMIN H. DUNNING

\section{$\overline{\text { PENN }}$}

University of Pennsylvania Press

Philadelphia 


\section{For Bob}

Copyright ( 2009 University of Pennsylvania Press

All rights reserved. Except for brief quotations used for purposes of review or scholarly citation, none of this book may be reproduced in any form by any means without written permission from the publisher.

Published by

University of Pennsylvania Press

Philadelphia, Pennsylvania 19104-4112

Printed in the United States of America on acid-free paper

$\begin{array}{llllllllll}10 & 9 & 8 & 7 & 6 & 5 & 4 & 3 & 2 & 1\end{array}$

Library of Congress Cataloging-in-Publication Data

Dunning, Benjamin H.

Aliens and sojourners : self as other in early Christianity / Benjamin H. Dunning. p. $\quad \mathrm{cm} .-$ (Divinations: rereading ancient religion)

ISBN: 978-0-8122-4156-3 (alk. paper)

Includes bibliographical references and index.

1. Self-Religious aspects-Christianity-History of doctrines-Early church, ca. 30-600. 2. Theological anthropology—Christianity-History of doctrines-Early church, ca. 30-600. 3. Strangers-Religious aspects-Christianity-History of doctrines-Early church, ca. 30-600. 4. Alienation (Theology). 5. Identification (Religion). 6. Other (Philosophy). I. Title

BT713.D86 2009

$270.1-\mathrm{dc} 22$

2008035362 